Füsun Gülderen Alacapınar' (PhD)

Necmettin Erbakan University

Faculty of Ahmet Kelesoglu Education, Konya, Turkey

Hatice Uysal ${ }^{2}$ (Mathematics Teacher)

Sefaköy Mehmet Tosun İmam Hatip Ortaokulu

Konya, Turkey
Original scientific paper

UDC: 37.025

DOI: $10.5937 /$ IstrPed2002265G

\title{
A META-ANALYSIS OF THE EFFECTIVENESS OF THE METHOD OF CREATIVE DRAMA IN MATH COURSES IN REGARD TO STUDENT SCORES IN ACHIEVEMENT, ATTITUDE AND RETENTION ${ }^{3}$
}

\begin{abstract}
In this study, pretest-posttest control group design thesis in experimental models was investigated by meta-analysis for pre-school, primary and secondary school mathematics classes based on creative drama method, between years 20002020 which are accepted by universities in Turkey. 3doctoral theses and 20 master's theses that are suitable for the problem of this research and have sufficient statistical data were included in the meta-analysis. In the analysis of data, meta-analysis of transaction effectiveness was used. In this study, the effect of creative drama method on students' academic achievement, retention(remembering) and affective (attitude) scores were examined. As a result of meta-analysis calculations, the effect size value of creative drama method on students' academic achievement scores was 0.926 , the effect size on retention scores was 1.414 and the effect size value on attitude scores was 0.600 . These values determined as a result of the analysis; shows that the effect size is wide for academic success and retention and medium for attitude. According to these findings, the academic success and retention of creative drama method in pre-school and elementary mathematics lessons is wide; it can be said that it affects attitude at a moderate level significantly.
\end{abstract}

Keywords: academic success, attitude, creative drama,effect value, meta-analysis, retention.

\section{Introduction}

Since the goal of education is to prepare students to life method and techniques used in education have to be in compliance with this goal (Ozsoy, 2003). The method of teachercentred lecturing, questions/answers that follow and making other do by demonstrating is one of the most common methods used in education and teaching (Aytas, 2013).The methods of teaching have their distinct importance in realizing the goals of education and in organizing education environments. It is essential to use methods and techniques fit for the process in order to achieve what is desired in teaching and learning. In other words, the success in the process of learning-teaching seems to be dependent upon the teaching methods that include

\footnotetext{
${ }^{1}$ fusunmireli@yahoo.com

²h.uysalll@hotmail.com
} 
a response to the question "How can I create a more effective learning environment?" by the teacher while designing relevant activities. Hence, allocating space to student-centred methods and techniques that ensure student participation to learning processes and learning by doing-experiencing is an important step in realizing a constructivist learning (Aykac \& Ulubey, 2008).

There are methods and techniques befitting constructivist approach including problem solving, case study, creative drama, project work, brain storming and six thinking hats (Aykac\&Ulubey, 2008). To instil in students a positive attitude to mathematics, it may be useful to change methods, techniques and strategies in teaching the course besides enriching it with various materials, making class environments friendlier and improving teacher-student communication Creative drama is one of these methods (Karapinarli, 2007).

Akdemir and Karakus (2016: 56) define creative drama as "workshop activities envisaging the attainment of specific objectives, composed of three parts as warming up, animation and assessment and carried out as a group with a leader without any limitation as to age and theme". Adiguzel's (2006: 21) definition is "engaging in animations around any topic together with a group, capitalizing on accumulated information and experience of group members, by using techniques like improvisation and role play. San (2002) maintains that creative drama is a method of teaching alternative to rote learning. Indeed, the contribution of creative drama to bringing up students focusing not on ends but the process, internalizing the meanings of concepts, capable of solving problems, thinking creatively and sharing their ideas with others instead of just memorizing what is transmitted as information (Ozsoy, 2010).

In creative drama the theme may just be anything: a specific event, an abstract-concrete situation, news in a paper, a cartoon and any piece of literature, an incomplete text, an experience, memory or a photograph. The subject matter of any course can be a material for proceeding with creative drama. Due to its multi-faceted functionality, creative drama is a method and discipline focusing on the process rather than the end which is effective in adapting many learning environments in the class to out of class environments. Since there is no ready text or script in creative drama experiences mostly emerge spontaneously in the process. As a group activity, creative drama may use stage techniques such as improvisation and role play (Adiguzel, 2006).

In creative drama activities it is the leader/teacher that designs, shapes and manages the process. He/she is the most important figure in creative drama process. The leader performs the function of breaking through when students are confronted with a problem and cannot progress, but does not know how the process will continue and end (Adiguzel, 2006). Through creative drama activities guided by an adult, students form and develop information, skills and emotions in interaction and communication with each other (Pinciotti, 1993).

In these activities, multi-dimensional education of the student, his/her active participation, and elements like communication among students and creativity can be experienced in learning environments instead of teacher's one-way information transfer (Adiguzel, 2006). By merging intellectual and physical activity, creative drama seeks to include all students in improvisations and process-related experiences (Pinciotti, 1993). Students are present in all domains of the course by thinking, talking, listening, focusing and acting (Annarella, 1999). 
Creative drama has three stages as preparation (warming up), animation and assessment (discussion). At the preparation stage where the leader is more active the objective is to carry students on to the next stage by creating group dynamics (Adiguzel, 2006). Warming up constitutes a stage where there is an effort to create group dynamics through inward-looking work based more on physical activity (Aykac \& Ulubey, 2008). Child games we all know can be used at this stage (Adiguzel, 2006) since games lay the basis of the drama method (Aytas, 2013). Animation is the stage where improvisation, role play and similar other techniques are used as starting point around a specific theme. Animations can be on individual basis or as groups (Adiguzel, 2006). At this stage students take part actively in the process of learning in line with instructions given and construct the knowledge by themselves (Aykac \& Ulubey, 2008). In assessment, which is the last stage there is discussion on issues and information that have been obtained. It is the issue of this stag whether what has been learned is transformed into achievement and whether this will have its effect on future life. The attitude scale may be used at the stage of assessment if the objectives of the study include cognitive achievements and if it is thought that an instrument measuring the level of knowledge would improve attitudes. Otherwise, assessment may remain limited to verbal sharing of opinions, attitudes and life experiences. It is possible to mould and change all these stages according to work done by the leader (teacher). The important point in creative drama work is to ensure that there is relationship between all activities and that activities support and complement each other and to determine whether these activities are effective in attaining envisaged achievements while bringing the issue to the appropriate group in appropriate time (Adiguzel, 2006).

Drama used in teaching may reduce student worries and stress related to the course (Masoum, Rostamy-Malkhalifeh \& Kalantarnia, 2013). Creative drama helps student's socialization. The student learns listening and expressing himself/herself (Ozsoy \& Yuksel, 2007). Children develop their communication skills by using their voices, hands, faces and bodies (Anthony, 2002). It helps examining cases and situations that are temporally and spatially unreachable by making them "experienced" (Kavcar, 1985). Students are more attentive in their class since creative drama activities interesting, motivating and amusing (Duatepe Paksu \& Ubuz, 2007).

On the basis of drama, information is transferred into life (Okvuran, 2003) which makes it long-lasting (Woods, 1990). It also facilitates making abstract concepts, phenomena or experiences concrete (Karapinarli, 2007).The active participation of students to drama practices helps them acquire new knowledge and experience (Yidiz, 2011). Children can learn to better understand themselves and others and their social awareness improve by working with and behaving like others. They develop awareness in what kind of impact does their social interactions and actions make on others (Anthony, 2002). Creative drama provides an environment fit for multiple intelligence by including verbal, physical, musical or visual elements in the process (Aykac \& Ulubey, 2008). It also enables students to intuit and feel any situation beyond merely grasping it (Kavcar, 1985).

Joint work in activities contributes to students' social, affectionate and critical skills (Chaviaris \& Kafoussi, 2010). Since drama requires students to think about a variety of ways to reach a target, it also encourages imagination and independent thinking (Anthony, 2002). It encourages students to work together and learn from each other (Duatepe Paksu \& Ubuz, 2007). It helps less talented students not much interested in the course to taste the feeling of belonging and success by engaging them in cooperation with other students (Karapinarli, 
2007).Creative drama has its long-term benefits in building problem solving and cooperation skills and capability to translate creative ideas into action (Pinciotti, 1993).

Since teacher-centred teaching methods accompanied by Q/A remain insufficient particularly in primary education math courses creative drama practices where students take active part have been started. Learning takes place by doing and experiencing through methods like game and creative drama, lessons become more interesting and thus learning gets easier. Ozsoy (2010) says creative drama used in math classes provides an opportunity of rehearsal for real life situations. Studies conducted so far suggest that creative drama activities in math courses support students in their cognitive achievement (Karapinarli, 2007; Saab, 1988), retention of what has been learned (Altindal, 2019; Karapinarli, 2007), problem solving strategies (Senol Ozyigit, 2011) and success in it (Tanriseven, 2000), interest in and attitude towards the course (Sahin, 2018; Timothy \&Apata, 2014), elimination of worries about mathematics and building of sense of self-sufficiency (Gedik, 2014), motivation (Borlat, 2018) and academic self-respect (Senol Ozyigit, 2011). In one of these studies Ozsoy (2003) found that creative drama method has its positive effect on student achievement in mathematics course. In interviews with experimental group students which was the qualitative part of the survey, students said they had not played such games in math courses before, they had fun while learning, they never get bored and they would like to have such activities more frequently though not in every class. In another study, Gedik (2014) found that creative drama practices yielded better outcomes in terms student skills in grasping and practicing compared to lecturing, discussion and $\mathrm{Q} / \mathrm{A}$ methods used in the control group. Another conclusion reached in the same study is that creative drama positively affects students' perception of self-sufficiency in math courses. Borlat (2018) too finds that creative drama activities significantly reduce students' worries about mathematics a course and augment their inner motivation. Altindal (2019) finds there is a significant difference in favour of creative drama method between experimental and control groups when it comes to scores in achievement, attitude and retention. In addition, going over students' daily notes about their drama activities it is found that students have fun in their class, express themselves better in these activities and can apply what they have learned to their daily lives.

\subsection{Survey Objective}

Studies in the field of education are increasing day bay day. The multiplicity of studies on similar subjects and their diverging conclusions make it difficult to obtain clear-cut knowledge. It is for these reasons that meta-analyses that make joint analysis of studies on similar topics are becoming more and more common (Akdemir \& Karakus, 2016). There are quite a number of studies at post-graduate level on the use of creative drama in primary education. The basic objective of the present study is to examine by using meta-analysis method data obtained from experimental studies on the use of creative drama in math courses at primary and secondary education levels and to explore the effect of this method and currently used one on student scores in academic achievement, attitude and retention.

\subsection{Problem Statement}

According to meta-analysis of studies on practices using and not using the method of creative drama, is there significant difference in scores of students in terms of academic achievement, retention and attitude? 


\subsubsection{Sub-Problems}

1. Does the meta-analysis of studies applying and not applying the method of creative drama point to significant difference with respect to students' academic achievement?

2. Does the meta-analysis of studies applying and not applying the method of creative drama point to significant difference with respect to retention scores of students?

3. Does the meta-analysis of studies applying and not applying the method of creative drama point to significant difference with respect to attitude scores of students?

\section{Methodology}

Meta-analysis surveying method was used in this study. Meta-analysis is a method that is used to reach an overall conclusion by statistically analysing a range of studies mode on the same topic(Sonmez \& Alacapinar, 2014). So, researchers can obtain in-depth information about a subject (Dincer, 2014).

\subsection{Data Collection Process}

A review of research involving creative drama activities at masters and doctoral level, shows that in Turkey there are many articles and researches on this topic. The dissertations completed between 1997-2000 which are covering the entire topic in Turkey, are not included in this meta-analysis research done. All data in meta-analysis studies should consist of independent studies (Ozbey \& Sarikaya, 2019). In addition, the fact that some articles are derived from master's or doctoral dissertations may cause the same data to be used twice. For these reasons, this study is limited to postgraduate dissertations. The dissertationincluded in the study for analysis consist of experimental design surveys with pre and post-test groups conduced to identify the effect of creative drama-based teaching in primary and secondary school math courses. The surveying of postgraduate theses asserted in Turkey was conducted on the database of YOK (The Council of Higher Education)National Thesis Centre in Turkish language (https://tez.yok.gov.tr/UlusalTezMerkezi/). Keywords used in search were "drama" and "matematik" in Turkish and "drama", "maths" and "mathematics" in English. Of academic theses reached, those that are of experimental nature with pre and post-test control groups related to mathematics courses in primary and secondary education were included in the study. All presenting sufficient statistical data (i.e. arithmetic average, standard deviation, etc.), the experimental group was selected from among those using creative drama method and control group from the current mode of teaching. In this study, the time interval of the thesis has been included in domestic meta-analysis was restricted in Turkey with master's and doctoral dissertations between 2000 and 2020.

The present study covers 23 postgraduate studies, consisting of 3 doctoral dissertations and 20 theses for master's degree conducted in the period 2000-2020 addressing the use of creative drama in primary school math courses. These studies with control and experimental groups are relevant to the problem, sub-problems and the objective of the present study. Table 1 shows the distribution of studies by years and types. 
Table 1. Distribution of Studies Included in Meta-Analysis by Years and Types

\begin{tabular}{cccc}
\hline Year & Master's Thesis & Doctoral Dissertation & Total \\
\hline 2000 & 1 & 0 & 1 \\
2003 & 1 & 0 & 1 \\
2004 & 1 & 1 & 2 \\
2006 & 1 & 1 & 2 \\
2007 & 2 & 0 & 2 \\
2011 & 1 & 1 & 2 \\
2012 & 2 & 0 & 2 \\
2014 & 2 & 0 & 2 \\
2015 & 2 & 0 & 2 \\
2017 & 2 & 0 & 2 \\
2019 & 5 & 0 & 5 \\
Total & 20 & 3 & 23 \\
\hline
\end{tabular}

From these 23 dissertations, 670utcomes were obtained in relation to scores in cognitive achievement, retention and attitude. Then, general effect was calculated on the basis of fixed effect model of meta-analysis used for continuous data. As a first step in this process, standardized and bias-corrected mean difference (Hedge's g) was calculated. Data collected are related to cognitive achievement, retention and attitude scores. Meta-analysis is a method used in statistically analysing multiple studies and reaching a general conclusion (Sonmez \& Alacapinar, 2014).

\section{Findings}

The findings obtained from the analysis of the data are as follows:

\subsection{Findings Related to the First Sub-Problem}

The first sub-problem of the study is whether there is significant difference in students' academic achievements according to the meta-analysis of studies in which method of creative drama is applied or not applied. Homogeneous distribution value, average effect size and confidence intervals of the 29 results related to the effect of creative drama method on academic achievement according to the statistical models related to the academic achievement of the students are given in Table 2:

Table 2. Homogeneous and Heterogeneous Distribution Values, Average Effect Sizes and Confidence Intervals of Studies Covered by Meta-Analysis on Cognitive Domain Scores of Students by Creative Drama Method with Respect to Effect Models

\begin{tabular}{|c|c|c|c|c|c|c|c|c|}
\hline \multirow{2}{*}{ Model Type } & \multirow{2}{*}{$\begin{array}{c}\text { Average } \\
\text { effect } \\
\text { size (ES) }\end{array}$} & \multirow{2}{*}{$\begin{array}{l}\text { Degree } \\
\text { of } \\
\text { freedom } \\
\text { (df) }\end{array}$} & \multirow{2}{*}{$\begin{array}{c}\text { Homogeneity } \\
\text { value }(\mathrm{Q})\end{array}$} & \multirow{2}{*}{$\begin{array}{c}\text { Chi } \\
\text { square } \\
\text { table } \\
\text { value } \\
\text { (Chi } \\
\text { Square) }\end{array}$} & \multirow{2}{*}{$\begin{array}{l}\text { Stand } \\
\text { ard } \\
\text { error } \\
(\mathrm{SE})\end{array}$} & \multirow{2}{*}{$1^{2}$} & \multicolumn{2}{|c|}{$\begin{array}{l}95 \% \text { Confidence } \\
\text { interval for effect size }\end{array}$} \\
\hline & & & & & & & $\begin{array}{c}\text { Lower } \\
\text { limit }\end{array}$ & $\begin{array}{l}\text { Upper } \\
\text { limit }\end{array}$ \\
\hline $\begin{array}{l}\text { Fixed Effects } \\
\text { Model }\end{array}$ & 0.825 & 28 & 182.263 & $\begin{array}{c}41.337 \\
2\end{array}$ & 0.050 & 84.638 & 0.726 & 0.923 \\
\hline $\begin{array}{l}\text { Random Effects } \\
\text { Model }\end{array}$ & 0.926 & 28 & 182.263 & $\begin{array}{c}41.337 \\
2\end{array}$ & 0.130 & & 0.672 & 1.180 \\
\hline
\end{tabular}


According to Table 2, the effect of creative drama methodused in teaching environment on student achievement/success can be said to be positive with the effect size value of 0.825 in the fixed effects model. Homogeneity test yields statistical value $Q$ as 182.263 . In chi-square table, the critical value is considered as about 41.3372 at significance level of $95 \%$ and with degree of freedom of 28 . Since 182.263 , the statistical value Q calculated in this study is greater than 41.3372 as critical value, it can be said that the distribution of effect sizes has a heterogeneous nature. Having 84.638 as calculated $I^{2}$ may be accepted as showing that effect size at heterogeneous level is high.

Since the distribution in the study has heterogeneous character, it was sought to avoid illusions deriving from this heterogeneous character of the sample by conducting analyses in line with random effects model (Celebi Yildiz, 2002).According to random effects model, meta-analysis of data from 29 studies gives the effect size as $\mathbf{E S}=\mathbf{0 . 9 2 6}$ with standard error of 0.130 in $95 \%$ confidence interval with upper and lower limits as 1.180 and 0.672 , respectively. It can be said that effect size value is in the category "large" according to Cohen's (2007), which suggests that the use of creative drama method in class teaching have its positive effect on academic achievement/success. Findings related to effect size of studies are given in Table 3 and Figure 1.

Table 3. Distribution of Effect Sizes in Studies Covered by Meta-Analysis on Cognitive Achievements of Students in Creative Drama Method According to the Classification Made by Cohen

\begin{tabular}{ccc}
\hline Effect Size Level & Frequency & Percentage \\
\hline Small & 7 & 24.13 \\
Medium & 9 & 31.03 \\
Large & 13 & 44.83 \\
Total & 29 & 100 \\
\hline
\end{tabular}

When table 3 is examined, it is seen that according to Cohen (1992), 13 studies have a large effect size, 9 studies have a medium effect size and 7 studies have a small effect size. 
Figure 1. Effect Size Related to Academic Success

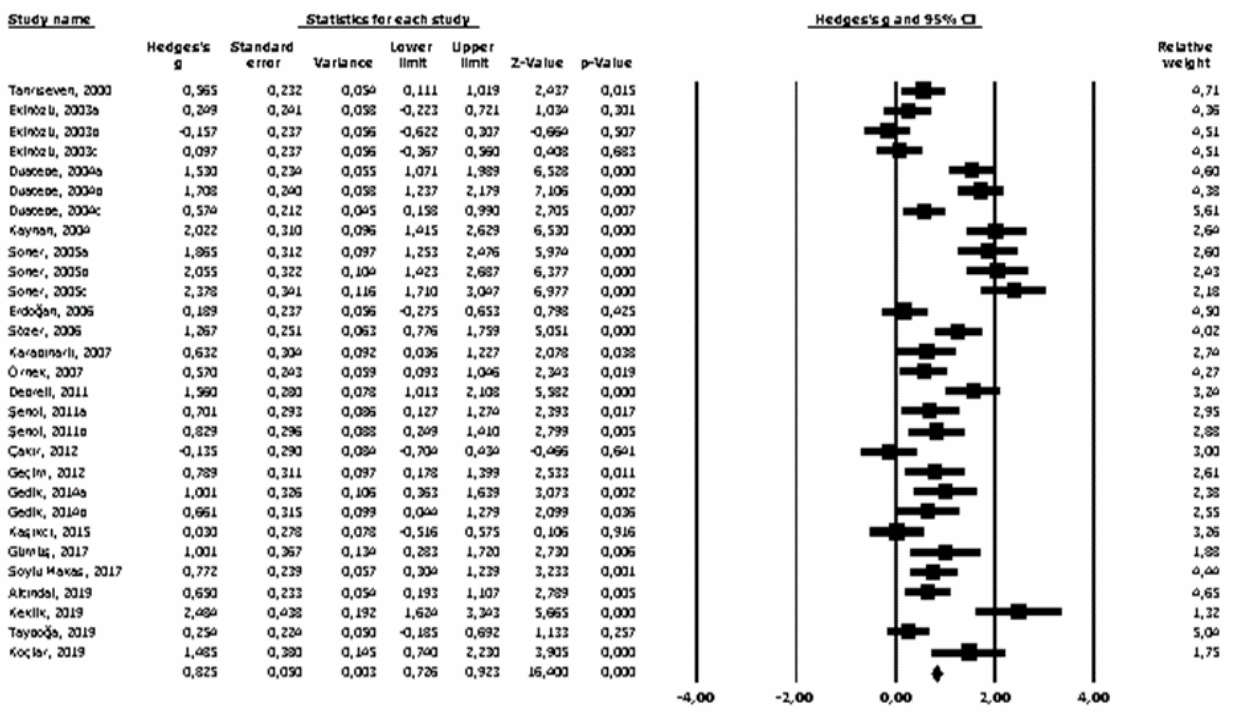

Favours A Favours B

Meta Analysis

As can be seen in Figure 1 lines on both sides of squares show the lower and upper limits of effect sizes in $95 \%$ confidence interval while the rhomb shows the overall effect size of studies. Taking a look we see 0.097 , as the smallest and 2.484as the largest effect size.It can be said that weight percentage given on the right of effect size values represents numerically the effect share of each study on meta-analysis outcome. Homogeneity/heterogeneity of studies covered by analysis and any bias can be shown with a funnel chart. Figure 2 gives the distribution of effect sizes of studies according to Hedges's as funnel chart (Funnel plot of precision). 
Figure 2: Distribution of Effect Sizes of Studies According to Hedges's g (Funnel Chart)

Funnel Plot of Precision by Hedges's g

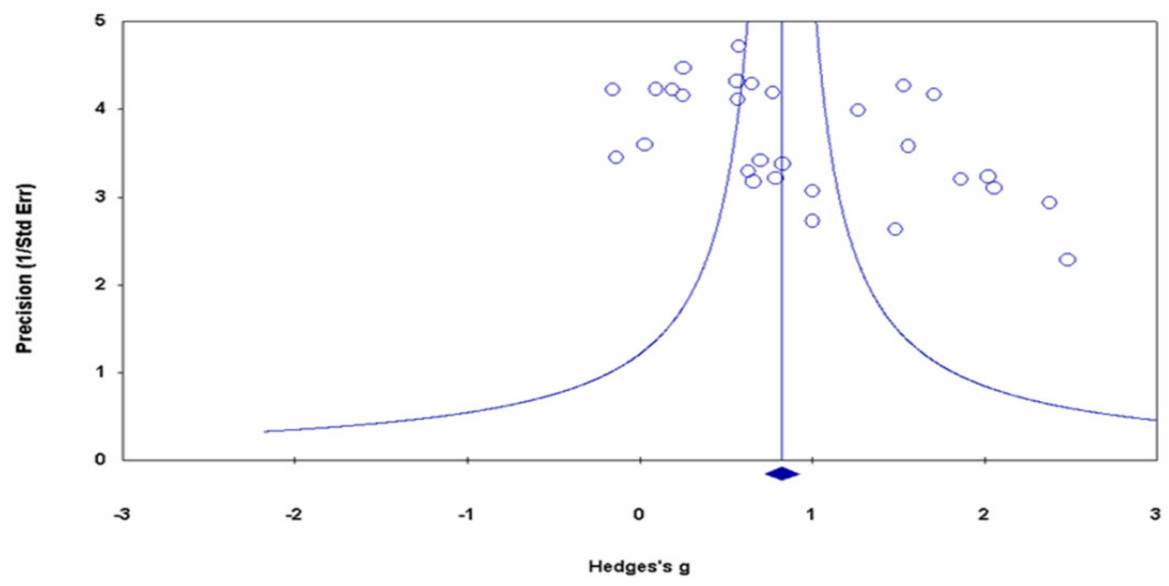

The funnel in the graphic is delimited by a \pm slope. According to this graphic some studies remain out of the slope curve which makes it possible to say that the group is heterogeneous. It may not yield sound results if assessment is made solely by taking a look the funnel graphic. More reliable outcome can be obtained if $\mathrm{Q}$ or $\mathrm{p}$ values are also considered (Dincer, 2014: 81).

\subsection{Findings Related to the Second Sub-problem}

The second sub-problem of the study is whether there is significant difference in students' retention scores according to the meta-analysis of studies covering groups in which creative drama method is applied or not applied. Homogenous distribution values, average effect sizes and confidence intervals of 13 outcomes in total covered by meta-analysis are given in Table 4 below according to statistical models related to students' retention scores.

Table 4. Homogeneous and Heterogeneous Distribution Values, Average Effect Sizes and Confidence Intervals of Studies on Retention Scores of Students Included in Meta-Analysis according to Effect Models

\begin{tabular}{|c|c|c|c|c|c|c|c|c|}
\hline \multirow{2}{*}{ Model Type } & \multirow{2}{*}{$\begin{array}{l}\text { Average } \\
\text { effect } \\
\text { size (ES) }\end{array}$} & \multirow{2}{*}{$\begin{array}{l}\text { Degree } \\
\text { of } \\
\text { freedom } \\
\text { (df) }\end{array}$} & \multirow{2}{*}{$\begin{array}{l}\text { Homogeneity } \\
\text { value (Q) }\end{array}$} & \multirow{2}{*}{$\begin{array}{c}\text { Chi } \\
\text { square } \\
\text { table } \\
\text { value } \\
\text { (Chi } \\
\text { Square) }\end{array}$} & \multirow{2}{*}{$\begin{array}{l}\text { Standard } \\
\text { error (SE) }\end{array}$} & \multirow{2}{*}{$\mathrm{I}^{2}$} & \multicolumn{2}{|c|}{$\begin{array}{l}95 \% \text { Confidence } \\
\text { interval for effect size }\end{array}$} \\
\hline & & & & & & & $\begin{array}{c}\text { Lower } \\
\text { limit }\end{array}$ & $\begin{array}{l}\text { Upper } \\
\text { limit }\end{array}$ \\
\hline $\begin{array}{l}\text { Fixed Effects } \\
\text { Model }\end{array}$ & 1.357 & 12 & 65.849 & 21.0261 & 0.078 & $\begin{array}{r}81 . \\
777\end{array}$ & 1.204 & 1.511 \\
\hline $\begin{array}{l}\text { Random } \\
\text { Effects Model }\end{array}$ & 1.414 & 12 & 65.849 & 21.0261 & 0.185 & & 1.051 & 1.776 \\
\hline
\end{tabular}

According to Table 4, the effect of creative drama method used in teaching environment on students' retention score can be said to be positive with the effect size value of 1.357 in the fixed effects model. Homogeneity test yields statistical value $Q$ as 65.849 . In chi-square table, the critical value is considered as about 21.0261 at significance level of $95 \%$ and with degree of freedom of 12 . Since 65.849 , the statistical value Q calculated in this study is greater than 21.0261as critical value, it can be said that the distribution of effect sizes has a heterogeneous 
nature. Having 81.777as calculated $\mathrm{I}^{2}$ may be accepted as showing that effect size at heterogeneous level is high.

Since the distribution in the study has heterogeneous character, it was sought to avoid illusions deriving from this heterogeneous character of the sample by conducting analyses in line with random effects model (CelebiYildiz, 2002). On this basis, the effectiveness of teaching with or without station technique is compared according to random effects model.According to random effects model, meta-analysis of data from 13 studies gives the effect size value as $\mathbf{E S}=\mathbf{1 . 4 1 4}$ with standard error of 0.185 in $95 \%$ confidence interval with upper and lower limits as 1.776 and 1.051 , respectively. It can be said that effect size value is in the category "large" according to Cohen's (1992),which suggests that the use of creative drama method in class teaching have its positive effect on students' retention scores. These suggest that average retention scores in groups where station technique is used are significantly higher than in other groups where station technique is not used.Findings related to effect size of studies are given in Table 5 and Figure 3.

Table 5. Distribution of Effect Sizes in Studies Covered by Meta-Analysis on Retention Scores of Students in Creative Drama Method According to the Classification Made by Cohen

\begin{tabular}{ccc}
\hline Effect Size Level & Frequency & Percentage \\
\hline Small & 1 & 7.70 \\
Medium & 2 & 15.38 \\
Large & 10 & 76.92 \\
Total & 13 & 100 \\
\hline
\end{tabular}

When table 5 is examined, it is seen that according to Cohen (1992), 10 studies have a large effect size,2 studies have a medium effect size and 1studies have a small effect size.

Figure 3.Effect Size Related to Retention Scores

\begin{tabular}{|c|c|c|c|c|c|c|c|}
\hline \multirow[t]{2}{*}{ Study name } & \multicolumn{7}{|c|}{ Statistics for each study } \\
\hline & Hedgesis & $\begin{array}{l}\text { Standard } \\
\text { efror }\end{array}$ & Vartance & $\begin{array}{l}\text { Lower } \\
\text { Ilimit }\end{array}$ & $\begin{array}{l}\text { Upper } \\
\text { ilmit }\end{array}$ & z-value & D-value \\
\hline Tanniseven, 2000 & 0,728 & 0,235 & $0,05 s$ & 0.258 & 1,182 & 3,101 & 0,002 \\
\hline Exisos U, 2003 & 1,550 & 0,271 & 0,073 & 1,020 & 2,020 & 5,705 & 0,000 \\
\hline Dusce os, zasas & 1,673 & 0,230 & 0,052 & 1,183 & 2,162 & 6,700 & 0,000 \\
\hline Dusceos, 20300 & 1,903 & 0,257 & 0,035 & $1, \infty 0 \mathrm{~s}$ & 2,011 & 7,028 & 0,000 \\
\hline xaymsn, 2000 & 2,150 & 0,317 & 0,100 & 1,533 & 2,775 & 6,2000 & 0,000 \\
\hline Sonet, 2005s & 1,928 & 0,315 & 0,099 & 1,310 & 2,505 & 6,113 & 0,000 \\
\hline Sone', 20050 & 1,912 & 0,315 & 0,099 & 1,296 & 2,523 & 6,078 & 0,000 \\
\hline Sonet, 2005s: & 2,408 & 0,320 & 0,121 & 1,205 & 3,169 & 7,158 & 0,000 \\
\hline Sozer, 2005 & 1,220 & 0,2009 & 0,052 & 0,735 & 1,713 & 8,907 & 0,000 \\
\hline ksosagyonts, 2007 & 0,232 & 0,323 & 0,095 & 0,188 & $1, \infty 97$ & 2,601 & 0,003 \\
\hline Ongex, 2007 & 0,720 & 0,205 & 0,051 & 0,238 & 1,202 & 2,925 & 0,003 \\
\hline $\operatorname{Cos} x^{\prime}, 2012$ & 0,113 & 0,230 & 0,020 & 0,053 & 0,681 & 0,329 & 0,697 \\
\hline \multirow[t]{2}{*}{ Gumbo, 2017} & 1,350 & 0,330 & 0,107 & 0,602 & 2,107 & 3,527 & 0,000 \\
\hline & 1,357 & 0,078 & 0,005 & 1,200 & 1,511 & 17,339 & 0,000 \\
\hline
\end{tabular}

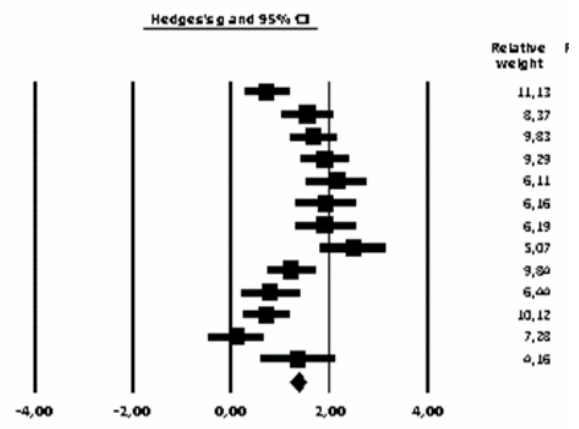

Favours A Favours B

Meta Analysis

As can be seen in Figure 3 lines on both sides of squares show the lower and upper limits of effect sizes in $95 \%$ confidence interval while the rhomb shows the overall effect size of studies. Taking a look at effect sizes we see 0.113 as the smallest and 2.488 as the largest 
effect size.Figure 4 gives the distribution of effect sizes of studies according to Hedges's as funnel chart (Funnel plot of precision).

Figure 4. Distribution of Effect Sizes of Studies According to Hedges's g (Funnel Chart)
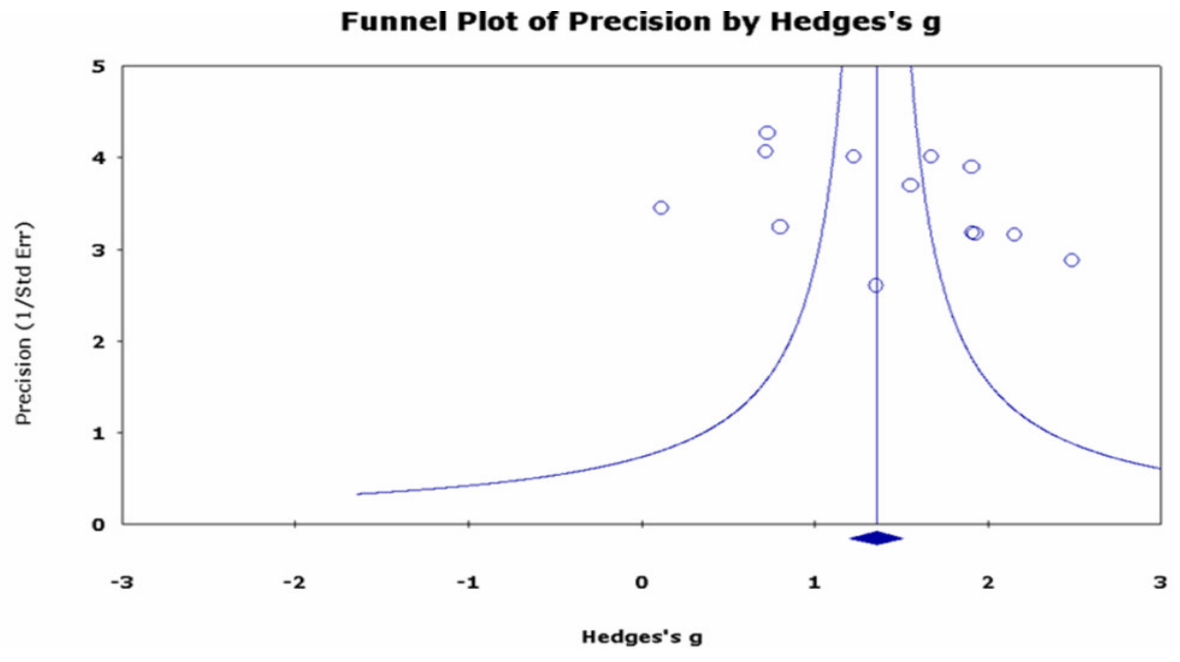

Figure 4 gives a funnel chart showing the distribution of effect sizes of studies. The funnel in the graphic is delimited by a \pm slope. According to this graphic some studies remain out of the slope curve which makes it possible to say that the group is heterogeneous. It may not yield sound results if assessment is made solely by taking a look at the funnel graphic. More reliable outcome can be obtained if $Q$ or $p$ values are also considered (Dincer, 2014: 81).

\subsection{Findings Related to the Third Sub-Problem}

The third sub-problem of the study is whether there is significant difference in students' attitude scores according to the meta-analysis of studies in which creative drama method is applied or not applied. Homogenous distribution values, average effect sizes and confidence intervals of 25 outcomes in total related to the effect of creative drama method on attitude scores in 23 academic theses covered by meta-analysis are given below in Table 6 .

Table 6. Homogeneous and Heterogeneous Distribution Values, Average Effect Sizes and Confidence Intervals of Studies on Attitude Scores of Students Included in Meta-Analysis according to Effect Models

\begin{tabular}{|c|c|c|c|c|c|c|c|c|}
\hline \multirow{2}{*}{ Model Type } & \multirow{2}{*}{$\begin{array}{l}\text { Average } \\
\text { effect } \\
\text { size (ES) }\end{array}$} & \multirow{2}{*}{$\begin{array}{l}\text { Degree } \\
\text { of } \\
\text { freedom } \\
\text { (df) }\end{array}$} & \multirow{2}{*}{$\begin{array}{l}\text { Homogeneity } \\
\text { value (Q) }\end{array}$} & \multirow{2}{*}{$\begin{array}{c}\text { Chi } \\
\text { square } \\
\text { table } \\
\text { value }\end{array}$} & \multirow{2}{*}{$\begin{array}{l}\text { Standard } \\
\text { error (SE) }\end{array}$} & \multirow{2}{*}{12} & \multicolumn{2}{|c|}{$\begin{array}{l}95 \% \text { Confidence } \\
\text { interval for effect size }\end{array}$} \\
\hline & & & & & & & $\begin{array}{l}\text { Lower } \\
\text { limit }\end{array}$ & $\begin{array}{l}\text { Upper } \\
\text { limit }\end{array}$ \\
\hline $\begin{array}{l}\text { Fixed Effects } \\
\text { Model }\end{array}$ & 0.576 & 24 & 97.643 & 36.4151 & 0.054 & $\begin{array}{c}75 . \\
42 \\
1\end{array}$ & 0.471 & 0.681 \\
\hline $\begin{array}{l}\text { Random } \\
\text { Effects Model }\end{array}$ & 0.600 & 24 & 97.643 & 36.4151 & 0.109 & & 0.387 & 0.814 \\
\hline
\end{tabular}


According to Table 6, the effect of station technique used in teaching environment on students' attitude scores can be said to be positive with the effect size value of 0.576 in the fixed effects model. Homogeneity test yields statistical value Q as 97.643 . In chi-square table, the critical value is considered as about 36.4151 at significance level of $95 \%$ and with degree of freedom of 24 . Since 97.643 , the statistical value Q calculated in this study is greater than 36.4151 as critical value, it can be said that the distribution of effect sizes has a heterogeneous nature. Having 75.421 as calculated $\mathrm{I}^{2}$ may be accepted as showing that effect size at heterogeneous level is high.

Since the distribution in the study has heterogeneous character, it was sought to avoid illusions deriving from this heterogeneous character of the sample by conducting analyses in line with random effects model (CelebiYildiz, 2002).According to random effects model, metaanalysis of data from 25 studies gives the effect size as $\mathbf{E S}=\mathbf{0 . 6 0 0}$ with standard error of 0.109 in $95 \%$ confidence interval with upper and lower limits as 0.814 and 0.387 , respectively. Findings related to effect size of studies are given in Table 7 and Figure 5.

Table 7. Distribution of Effect Sizes in Studies Covered by Meta-Analysis on Attitude Scores of Students in Creative Drama Method According to the Classification Made by Cohen

\begin{tabular}{ccc}
\hline Effect Size Level & Frequency & Percentage \\
\hline Small & 7 & 28 \\
Medium & 9 & 36 \\
Large & 9 & 36 \\
Total & 25 & 100 \\
\hline
\end{tabular}

When table 7 is examined, it is seen that according to Cohen (1992), 7 studies have a large effect size, equal number of studies (9) have medium and small effect size.

Figure 5. Effect Size Values Related to Attitude Scores

\begin{tabular}{|c|c|c|c|c|c|c|c|}
\hline \multirow[t]{2}{*}{ Study name } & \multicolumn{7}{|c|}{ Statistics for each studv } \\
\hline & Hedgesis & $\begin{array}{c}\text { Standard } \\
\text { erter }\end{array}$ & vartance & $\begin{array}{l}\text { Lower } \\
\text { Himt }\end{array}$ & $\begin{array}{l}\text { Uppet } \\
\text { Iltmit }\end{array}$ & z-value & D-value \\
\hline Exinsat, 2003 & 0,052 & 0,237 & 0,055 & 0,585 & 0,001 & 0,250 & 0,792 \\
\hline Dusceoce, zojas & $0,6 \infty$ & 0,213 & 0,005 & 0,285 & 1,052 & 3,021 & 0,003 \\
\hline Dusceos, 20000 & $0,6 \infty 9$ & 0,213 & 0,005 & 0,230 & 1,056 & 3,039 & 0,032 \\
\hline Koynson, 2000 & 0,012 & 0,250 & 0,050 & 0,035 & 0,909 & 1,627 & 0,100 \\
\hline Soner, zoss & 1,259 & 0,235 & 0,031 & 0,201 & 1,817 & $\Delta, \Delta 21$ & 0,000 \\
\hline $0 \mathrm{ingx}, 20070$ & 0,553 & 0,203 & 0,059 & $0, \infty 20$ & 1,032 & 2,259 & 0,022 \\
\hline Oinex, 20070 & $-0,050$ & 0,202 & 0,058 & $-0,937$ & 0,010 & $-1,920$ & 0,0 ss \\
\hline Dedell, zous & 1,1009 & 0,203 & 0,079 & 0,600 & 1,699 & $\Delta, 099$ & 0,000 \\
\hline Develli, zoulo & 0,733 & 0,259 & 0,072 & 0,205 & 1,300 & 2,870 & 0,020 \\
\hline Dedrell, an1k & 1,016 & 0,231 & 0,020 & 0,206 & 1,996 & 0,872 & 0,000 \\
\hline Develli, zolld & 1,690 & 0,303 & 0,092 & 1,100 & 2,283 & 5,587 & 0,000 \\
\hline nenol, mils & 0,781 & 0,295 & 0,037 & 0,203 & 1,399 & 2,6099 & 0,053 \\
\hline nenol, 20110 & 0,551 & 0,289 & 0,020 & 0,016 & 1,118 & 1,900 & 0,057 \\
\hline $\cos 100,2012$ & $-0,053$ & 0,300 & 0,090 & 0,653 & 0,521 & 0,221 & 0,825 \\
\hline Ceylan, 201as & 0,632 & 0,300 & 0,092 & 0,03 & 1,228 & 2,0000 & 0,032 \\
\hline Ceylan, 201000 & 1,321 & 0,323 & 0,103 & 0,678 & 1,955 & $\Delta, 027$ & 0,000 \\
\hline Ceylon, 2010< & 0,829 & 0,303 & 0,095 & 0,223 & 1,035 & 2,681 & 0,007 \\
\hline Godik, 2010 & 1,050 & 0,323 & 0,107 & 0,012 & 1,697 & 3,217 & 0,021 \\
\hline Kaøȳxý, 2015 & 0,023 & 0,278 & 0,078 & 0,523 & 0,969 & 0,033 & 0,930 \\
\hline Soylu Haks, 2017 & 0,832 & 0,200 & 0,058 & 0,352 & 1,303 & 3,458 & 0,021 \\
\hline aryinsol, 2019 & 0,851 & 0,237 & 0,095 & 0,335 & 1,316 & 3,535 & 0,000 \\
\hline Ýlus lone $T \in 21,20180$ & 0,577 & 0,250 & 0,081 & 0,000 & 1,130 & 2,030 & 0,002 \\
\hline Ýlas lone Teal, 20190 & 0,518 & 0,233 & 0,050 & $-1,073$ & 0,037 & $-1,830$ & 0,057 \\
\hline Tayosto, 2019 & 0,378 & 0.225 & 0,051 & 0,053 & 0,819 & 1,679 & 0,093 \\
\hline 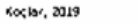 & $-0,05 s$ & 0,335 & 0,112 & 0,712 & 0,601 & 0,165 & 0,259 \\
\hline & $0,5 \times 6$ & 0,050 & 0,003 & $0, \Delta 71$ & 0,681 & 10,755 & 0,000 \\
\hline
\end{tabular}

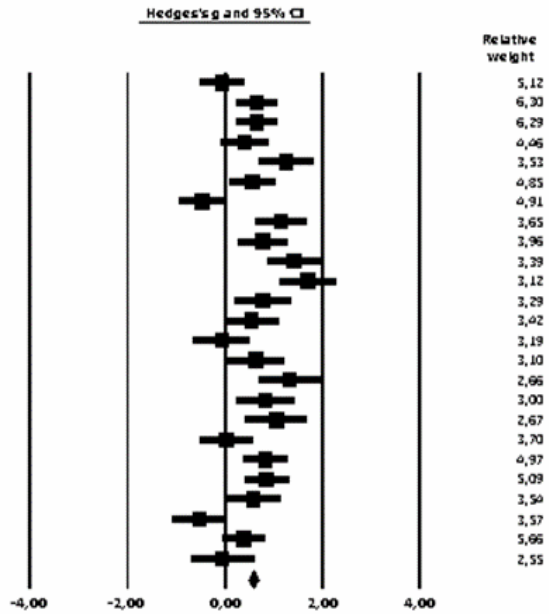

Favours A Favours B 
As can be seen in Figure 5 lines on both sides of squares show the lower and upper limits of effect sizes in $95 \%$ confidence interval while the rhomb shows the overall effect size of studies. Taking a look at effect sizes we see 0.023 as the smallest and 1.321 as the largest effect size.Figure 6 gives the distribution of effect sizes of studies according to Hedges's as funnel chart (Funnel plot of precision).

Figure 6. Distribution of Effect Sizes of Studies According to Hedges's g (Funnel Chart)

Funnel Plot of Precision by Hedges's g

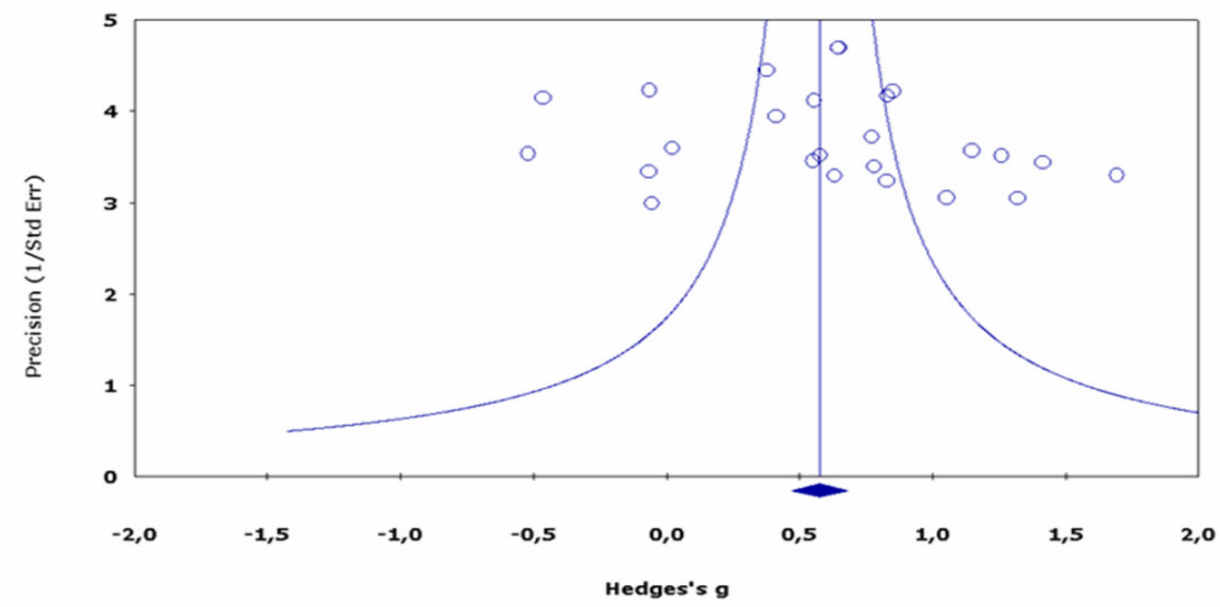

Figure 6 gives the funnel chart showing the distribution of effect size in studies. The funnel in the graphic is delimited by a \pm slope. According to this graphic some studies remain out of the slope curve which makes it possible to say that the group is heterogeneous. It may not yield sound results if assessment is made solely by taking a look at the funnel graphic. More reliable outcome can be obtained if $Q$ or $p$ values are also considered (Dincer, 2014: 81).

\section{Discussion and Conclusion}

The objective is to determine the overall effect on variables of achievement, retention and attitude on the basis of studies made subject to meta-analysis. According to 3 doctoral and 20 master's theses delivered in Turkey, teaching based on creative drama method has its positive effect on scores related to academic achievement and attitude. Moving on from Cohen's classification (1992) we find that the size of effect falls in the large interval with respect to academic achievement. In other words, the size of the effect of the use of creative drama in mathematics courses is large in terms of academic achievement. Indeed, many studies found in academic literature suggest that the method of creative drama has its significant effect on the academic achievement of students. The study by Ozsoy (2003), for example, concludes that creative drama has its positive effect on student performance in mathematics course. In interviews with experimental group students which was the qualitative part of the survey, students said they had not played such games in math courses before, they had fun while learning, never get bored and they would like to have such activities more frequently though not in every class. In another experimental study Masoumet. al. (2013) found that using drama in teaching mathematics helps students learn relevant concepts better than in conventional methods of teaching. In a study focusing on $6^{\text {th }}$ grade mathematics course Saab (1988) 
concludes that the method of creative drama applied in the experimental group has its effect on academic achievement of students. Contrary to these findings, Kariuki and Humphrey (2006) who worked with low-performing students in mathematics concluded that creative drama makes no significant difference in students' performance in mathematics.

It is observed that other meta-analysis studies on drama-based have similar results. For example, in a meta-analysis covering 51 studies, Bahadirhan (2019) found that drama method based teaching brings in higher academic performance relative to the conventional method. Examining 27 academic theses, Akdemir and Karakus (2016) found that the method of creative drama used in courses affects academic achievement positively and this positive effect varies with respect to the level of teaching and type of course. The study shows that the largest effect size is in primary education level. In another meta-analysis, Canturk (2016) finds that the method of creative drama used in mathematics course yields relatively more successful results than in conventional teaching. The study also finds that the size of effect on academic achievement does not vary with respect to mathematics course, level of education, duration of practice and sample size. Parallel to this, Ozbey's (2017) meta-analysis courses taught in Turkey through creative drama improves academic achievement compared to other methods and applications. In another meta-analysis examining the effect of creative drama on academic achievement, Ulubey and Toraman (2015) concludes that the method yielded positive outcomes. Differing from these studies investigating the effectiveness of the drama method, meta-analysis conducted by Lee et. al. (2015) concluded that the method of creative drama has its medium level effect on the academic achievement of students.

The present study finds the size of effect calculated according to Cohen's classification (1992) large with respect to retention scores. It can thus be said that creative drama used in primary school mathematics courses largely affects the retention scores of students. Another study reaching parallel conclusions is by Karapinarli (2007) who found that the effect of the method on retention scores is significant. The researcher mentions the following as the factors that enhance retention in creative drama: Enhancement of the imaginative power of the student; students managing to translate the abstract world of mathematics into concrete as a result of the method; being aware that mathematics is used in daily life; possibility of making connotations to mathematics while intensifying on themselves, objects and situations; and interesting and attractive nature of the method. Ekinozu (2003) finds that relative to plain lecturing, the drama method makes it easier for $8^{\text {th }}$ grade students to retain what they have learned in their mathematics courses. Reaching a similar finding, Altindal (2019) and Gumus (2017) find that creative drama-focused teaching of mathematics contributes more to student's retention of knowledge relative to standard activities already existing in curricula. In a qualitative study Akyazi (2019) mentions a remark made by a student "l'll never forget this" as an indicator of the effect of the method on retention. Soylu Makas (2017) argues that creative drama is more effective in terms of retaining what has been learned relative to what presently exists in the curricula.

This study finds, according to the classification made by Cohen (1992), the size of effect related to attitude scores as medium. In other words, the method of creative drama in primary school math courses affect students' attitude towards the course at medium level. In their meta-analysis covering 30 studies Toraman and Ulubey (2016) find that the method of creative drama positively affect the student attitude towards the course, but at a low level Sahin (2018) concludes that students do have fun and learn when the method of creative drama is employed in math courses. In their study Timothy and Apata (2014) state that positive attitude 
changes in the experimental group of students with which creative drama is applied are more pronounced than in the control group. In another survey Ozbey (2017) finds that the drama method has its medium size positive effect on attitude. It is also found that the size of the effect of drama method on attitude varies significantly with respect to levels of education. Contrary to these findings, Ekinozu (2003) finds that the drama method and the present method have the same effect on the attitude of students. According to Kariuki and Humphrey (2006), creative drama makes no significant difference in course-related attitude of lowperforming students. Lee et. al (2015) concludes in their meta-analysis that the drama method has its positive but small effect on the attitude of students. Saab (1988) found that the creative drama method used in $6^{\text {th }}$ grade mathematics course had no significant effect on the attitude of students. The difference in effect sizes between studies conducted abroad and in Turkey can be attributed to cultural differences (Ozbey, 2017). It can also be said that differing results in attitude scores derive from the fact that attitude is something too abstract and subjective in identifying changes occurring in short-term (Zakariaet.al., 2010); the formation and evolution of attitudes take time.

Mathematics is a course that contains information hard to acquire due to the very nature of the course itself. The task of the teacher in this course is to arrange learning environments in which students construct what they learn through some meaningful experiments (Sahin, 2018). Teachers have their important responsibilities in preparing creative drama activities and leading the process. According to a study by Yildiz (2011), a half of math teachers consider themselves as competent in applying creative drama in math courses while the other half does not. Teachers planning to use creative drama in their classes must first have mastered mathematics as their branch and then to be receptive to new developments in creative drama and follow sources in this field. Otherwise, it is inevitable for teachers not well equipped in creative drama to face problems in their classes (Yildiz, 2011).

There are many variables affecting learning outcomes. One of these is the active participation to education environment by the student (Alacapinar\&Uysal, 2020). Through drama experience, the learner creates situations in which issues transform into sustained behaviour. The most important characteristic of creative drama with respect to learning is its integrated status with cognitive, affective, social and psychomotor competencies (Adiguzel, 2006). In sum, creative drama as a method plays a significant role in improving the academic achievement of students (Akdemir\&Karakus, 2016), enhancing their level of retention and development of positive attitude to mathematics by providing environments that facilitate active and effective learning.

\section{Suggestions}

The following suggestions can be made to researchers and practitioners in the light of conclusions reached:

\subsection{Suggestions for Researchers}

- There can be further meta-analyses on the method of creative drama that include studies made abroad as well.

- There can be comparative analyses of studies on creative drama conducted in the country and abroad. 
- There can be a move towards a new theory of learning-teaching on the basis of the outcomes of these meta-analyses.

- The present study examines the effect of the creative drama method on mathematicsrelated academic achievement, levels of recalling and attitude scores of primary and secondary school students. There can also be meta-analyses on the effect of the method of creative drama with respect to different branches and levels of education.

\subsection{Suggestions for Practitioners}

- Teachers can accord more space to the method of creative drama in their classes which is more effective in terms of academic achievement, retention and attitude than the current method of teaching.

- Teachers can make use of different methods and materials that help students develop a more positive attitude to mathematics.

\subsection{Suggestions for Teacher Training Institutions}

- Organization of creative drama activities in math courses requires mastery in this method. In this context, teachers may be enlisted in in-service training to use creative drama more effectively in their classes.

- Creative drama can be taught in schools as a course at least for a term.

- Math textbooks may allocate space to drama and other active learning methods which are presently non-existent.

- In schools, there may be drama workshops where students can act in ease.

\section{References}

Adiguzel, O. (2006). Yaratici drama kavrami, bilesenleri ve asamalari. Yaratici Drama Dergisi, 1(1), 17-29.

Akdemir, H., \& Karakus, M. (2016). Yaratici drama yonteminin akademik basari uzerine etkisi: Bir meta-analiz calismasi. International Journal of Active Learning, 1(2), 55-67.

Akyazi, N. (2019). Drama yontemi ile tam sayılarla toplama isleminin ogretimi: altinci sinif ogrencilerinden yansimalar. (Master's thesis). Accessed from YOK database (Thesis No: 584097).

Alacapinar, F. G., \& Uysal, H. (2020). Effect of station technique in classroom teaching: A metaanalysis study. Research on Education and Psychology (REP), 4(Specila Issue), 88-106.

Altindal, G. (2019). Ilkokul 3. sinif matematik dersinde yaratici drama yonteminin ogrencilerin basarilarina, tutumlarina ve bilgilerinin kaliciligina etkisi. (Master's thesis). Accessed from YOK database (Thesis No: 568542).

Anthony, S. C. (2002). Reasons for using creative drama in education. Retrived from (22 April 2020): http://www.susancanthony.com/res/tchr/drama.html

Aykac, N., \& Ulubey, O. (2008). Yaratici drama yontemi ile yapilandirmacilik iliskisinin 2005 MEB ilkogretim programlarinda degerlendirilmesi. Yaratici Drama Dergisi, 3(6), 25-42.

Aytas, G. (2013). Egitim ve ogretimde alternatif bir yontem: Yaratici drama. Adiyaman Universitesi Sosyal Bilimler Enstitusu Dergisi, 6(12), 35-54.

Bahadirhan, D. (2019). Ortaokul ve liselerde drama yontemi ile yapilan calismalarin etkililiginin bazi degiskenler acisindan incelenmesi: bir meta-analiz calismasi. (Master's thesis). Accessed from YOK database (Thesis No: 607499). 
Borlat, G. (2018). Yaratici drama yonteminin matematik kaygisi ve matematik motivasyonuna etkisi. (Master's thesis). Accessed from YOK database (Thesis No: 524662).

Cakir, B. E. (2012). Geleneksel ogretim yontemleri ile dramatizasyon yonteminin ilkogretim 2. sinif matematik dersinde, ogrencilerin akademik basari ve kavramların kalicilik duzeylerine etkisinin karsilastirilmasi. (Master's thesis). Accessed from YOK database (Thesis No: 313084).

Canturk Gunhan, B. (2016). The effect of drama based learning applied in Turkey on success of mathematics: A meta analysis study. International Online Journal of Educational Sciences, 8(2), 145-162.

Celebi Yildiz, N. (2002). Verilerin degerlendirilmesinde meta analiz.(Master's thesis). Accessed from YOK database (Thesis No: 126592).

Ceylan, H. (2014). 6. sinif matematik dersi esitlik ve denklem konusunun drama yontemi kullanılarak anlatilmasinin ogrenci tutumlarina etkisi.(Master's thesis). Accessed from YOK database (Thesis No: 366396).

Chaviaris, P., \& Kafoussi, S. (2010). Developing students' collaboration in a mathematics classroom through dramatic activities. International Electronic Journal of Mathematics Education, 5(2), 91-110.

Cohen, J. (1992). Statistical power analysis. Current Directions in Psychological Science, 1(3), 98101.

Debreli, E. (2011). The effect of creative drama based instruction on seventh grade students' achievement in ratio and proportion concepts and attitudes toward mathematics. (Master's thesis). Accessed from YOK database (Thesis No: 300746).

Demiray, P. (2013). Proje tabanli ogrenme modelinin etkililigi: Bir meta analiz calismasi[The effect of project based learning method: A meta analytic study] (Master's thesis, Ankara University, Ankara, Turkey). Retrieved from https://tez.yok.gov.tr/UlusalTezMerkezi/

Dincer, S. (2014). Egitim bilimlerinde uygulamali meta-analiz. Ankara: Pegem Akademi.

Duatepe Paksu, A.,\& Ubuz, B. (2007). Yaratici drama temelli matematik dersleri hakkinda ogretmen gorusleri. Yaratici Drama Dergisi, 1(3-4), 193-205.

Duatepe, A. (2004).The effects of drama based instruction on seventh grade students' geometry achievement, van Hiele geometric thinking levels, attitude toward mathematics and geometry. (Doctorate dissertation). Accessed from YOK database (Thesis No: 153158).

Ekinozu, I. (2003). Ilkogretimde permutasyon ve olasilik konusunun dramatizasyon ile ogretiminin basariya etkisinin incelenmesi. (Master's thesis). Accessed from YOK database (Thesis No: 124921).

Erdogan, S. (2006). Alti yas grubu cocuklarina drama yontemi ile verilen matematik egitiminin matematik yetenegine etkisinin incelenmesi. (Doctorate dissertation). Accessed from YOK database (Thesis No: 182715).

Gecim, A. D. (2012). The effect of creative drama based instruction on seventh grade students' mathematics achievement in probability concept and their attitudes toward mathematics. (Master's thesis). Accessed from YOK database (Thesis No: 321117).

Gedik, O. (2014). Matematik derslerinde kullanilan yaratici drama yonteminin ogrencilerin farkli ogrenme duzeylerine ve oz-yeterlik algilarina etkisinin belirlenmesi. (Master's thesis). Accessed from YOK database (Thesis No: 412190).

Gul Gumus, H. (2017). Matematik ogretiminde yaratici drama yonteminin ogrencilerin basarilarina, tutumlarina ve ogrenmenin kaliciligina etkisi. (Master's thesis). Accessed from YOK database (Thesis No: 498180).

Ilaslaner Terzi, P. (2019). Ortaokul 6. sinif matematik dersinde yaratici dramanin bir yontem olarak kullanilmasinin matematige yonelik tutuma ve kaygiya etkisi. (Master's thesis). Accessed from YOK database (Thesis No: 587094). 
Karapinarli, R. (2007). Ilkogretim 7. sinif matematik dersinde yaratici drama yonteminin ogrencilerin basari ve kalicilik duzeyine etkisi. (Master's thesis). Accessed from YOK database (Thesis No: 209057).

Kariuki, P., \& Humphrey, S. G. (2006). The effects of drama on the performance of at-risk elementary math students.A paper presented at the Annual Conference of the MidSouth Educational Research Association Birmingham, Alabama.

Kasikci, M. (2015). Matematik tarihi dersinde drama yonteminin ilkogretim matematik ogretmen adaylarinin bilgi, inanc ve tutumlarina etkisi. (Master's thesis). Accessed from YOK database (Thesis No: 395275).

Kavcar, C. (1985). Orgun egitimde dramatizasyon. Egitim ve Bilim, 56, 32-41.

Kayhan, H. C. (2004). Yaratici dramanin ilkogretim 3. sinif matematik dersinde ogrenmeye, bilgilerin kaliciligina ve matematige yonelik tutuma etkisi. (Master's thesis). Accessed from YOK database (Thesis No: 144994).

Keklik, A. (2019). Bir yontem olarak yaratici dramanin matematiksel modelleme gerektiren problemlerde etkililigi. (Master's thesis). Accessed from YOK database (Thesis No: 579205).

Koclar, N. (2019). Yaratici drama yontemiyle cebirsel ifadelerin ogretimi. (Master's thesis). Accessed from YOK database (Thesis No: 564228 ).

Lee, B. K., Patall, E. A., Cawthon, S. W., \& Steingut, R. R. (2015). The effect of drama based pedagogy on preK-16 outcomes: A meta-analysis of research from 1985 to 2012. Review of Educational Research, 85(1), 3-49.

Masoum, E., Rostamy-Malkhalifeh, M., \& Kalantarnia, Z. (2013).A study on the role of drama in learning mathematics. Mathematics Education Trends and Research, 1-7. doi:10.5899/2013/metr-00016

Okvuran, A. (2003). Drama ogretmenin yeterlilikleri. Ankara Universitesi Egitim Bilimleri Fakultesi Dergisi, 36(1-2), 81-87.

Ornek, S. (2007). Trigonometrik kavramlarin canlandirma yontemiyle ogrenilmesinin ogrencilerin matematik basarisina etkisi. (Master's thesis). Accessed from YOK database (Thesis No: 210283).

Ozbey, O. F. (2017). Turkiye'de drama yontemi ile yapilan calismalarin etkililiginin incelenmesi: Bir meta analiz calismasi.(Master's thesis). Accessed from YOK database (Thesis No: 485886).

Ozbey, O. F., \& Sarikaya, R. (2019). Turkiye'de drama yontemi ile yapilan calismalarin etkililiginin incelenmesi: Bir meta-analiz calismasi. Gazi Egitim Bilimleri Dergisi, 5(Special issue), 231-253.

Ozsoy, N. (2003). Ilkogretim matematik derslerinde yaratici drama yonteminin kullanilmasi. Balıkesir Universitesi Fen Bilimleri Enstitusu Dergisi, 5(2), 112-119.

Ozsoy, N. (2010). Matematik ogretiminde alternatif etkinlikler "Yaratici drama uygulamalari". Aydin: Adnan Menderes Universitesi.

Ozsoy, N.,\& Yuksel, S. (2007). Matematik ogretiminde drama. Dokuz Eylul Universitesi Buca Egitim Fakultesi Dergisi, 21, 32-36.

Ozyigit Senol, E. N. (2011). Ilkogretim matematik dersinde yaratici drama uygulamalarinin ogrencilerin problem cozme stratejileri, basari, benlik kavrami ve etkilesim oruntuleri uzerindeki etkisi. (Doctorate dissertation). Accessed from YOK database (Thesis No: 296488).

Pinciotti, P. (1993). Creative drama and young children: The dramatic learning connection. Arts Education Policy Review, 94(6), 24-28.

Saab, J. F. (1988). The effects of creative drama methods on mathematics achievement, attitudes and creativity. Dissertation Abstracts International. DAI-A 48/10, 2538. 
Sahin, B. (2018). Yaratici drama ile matematik ogreniyorum. Arastırma Temelli Etkinlik Dergisi (ATED), 8(1), 37-50.

San, I. (2002). Yaratici drama-egitsel boyutlari. In O. Adiguzel(Ed), Yaratici Drama (pp. 81-90). Ankara: Naturel Kitap.

Senol Ozyigit, E. N. (2011). Ilkogretim matematik dersinde yaratici drama uygulamalarinin ogrencilerin problem cozme stratejileri, basari, benlik kavrami ve etkilesim oruntuleri uzerindeki etkisi. (Master's thesis). Accessed from YOK database (Thesis No: 296488).

Soner, S. (2015). Ilkogretim matematik dersi kesirli sayilarda toplama-cikarma isleminde drama yontemi ile yapilan ogretimin etkililigi. (Master's thesis). Accessed from YOK database (Thesis No: 188011).

Sonmez, V., \& Alacapinar, F. G. (2014). Orneklendirilmis bilimsel arastırma yontemleri. Ankara: Ani.

Soylu Makas, F. (2017). Yaratici drama yonteminin dorduncu sinif matematik dersinde basri, tutum ve ogrenmenin kaliciligina etkisi.(Master's thesis). Accessed from YOK database (Thesis No: 471955).

Sozer, N. (2006). Ilkogretim 4. sinif matematik dersinde drama yonteminin ogrencilerin basarilarina tutumlarina ve ogrenmenin kaliciligina etkisi. (Master's thesis). Accessed from YOK database (Thesis No: 191047).

Studies included in the meta-analysis:

Tanriseven, I. (2000). Matematik ogretiminde problem cozme stratejisi olarak dramatizasyonun kullanılmasi.(Master's thesis). Accessed from YOK database(Thesis No: 102381).

Tayboga, D. (2019). Yaratici drama yontemiyle zenginlestirilmis matematik ogretiminin ogrencilerin ogrenme duzeylerine ve akademik ozguvenlerine etkisi. (Master's thesis). Accessed from YOK database (Thesis No: 583901).

Timothy, J., \& Apata, F. S. (2014). Effects of creative drama-based instruction on basic science achievement and scientific attitudes in Lagos state.Journal of Science, Technology \& Education (JOSTE), 2(2), 59-65.

Toraman, C., \& Ulubey, O. (2016). The effect of creative drama method on the attitudetowards course: A meta-analysis study. Journal of Educational Sciences Research,6(1), 87-115.

Ulubey, O., \& Toraman, C. (2015). Yaratici drama yonteminin akademik basariya etkisi: Bir meta-analiz calismasi. Mustafa Kemal Universitesi Sosyal Bilimler Enstitusu Dergisi, 12(32), 195-220.

Yildiz, E. (2011). Yaratici dramayi matematik ogretiminde yontem olarak kullanan ogretmenlerin ve ogretim elemanlarinin yonteme iliskin goruslerinin degerlendirilmesi.(Master's thesis). Accessed from YOK database (Thesis No: 302027).

Zakaria, E., Chin, L. C., \& Daud, Md. Y. (2010). The effects of cooperative learning on students' mathematics achievement and attitude towards mathematics. Journal of Social Sciences, 6(2), 272-275.

\section{Biographical notes:}

Hatice UYSAL completed her bachelor's degree on Department of Elemantary Mathematics Education at NecmettinErbakan University in 2011. She finished to study for master's degree in 2019. Now she is a PhD student in Curriculum and Instruction at NecmettinErbakan University, AhmetKeleşoğlu Faculty of Education. Also, since 2012, she has been working as a mathematics teacher in Konya/Turkey. 
Füsun Gülderen ALACAPINAR is still continuing her work life at Necmettin Erbakan University in Turkey and lectures various lessons such as teaching principles and methods, curriculum development, scientific research methods, special teaching methods and on-site applications. 